\title{
POST-SOCIALIST URBAN GROWTH OF BUCHAREST, ROMANIA - A CHANGE DETECTION ANALYSIS ON LANDSAT IMAGERY (1984-2010)
}

Bogdan Mihai, Constantin Nistor, Gabriel Simion

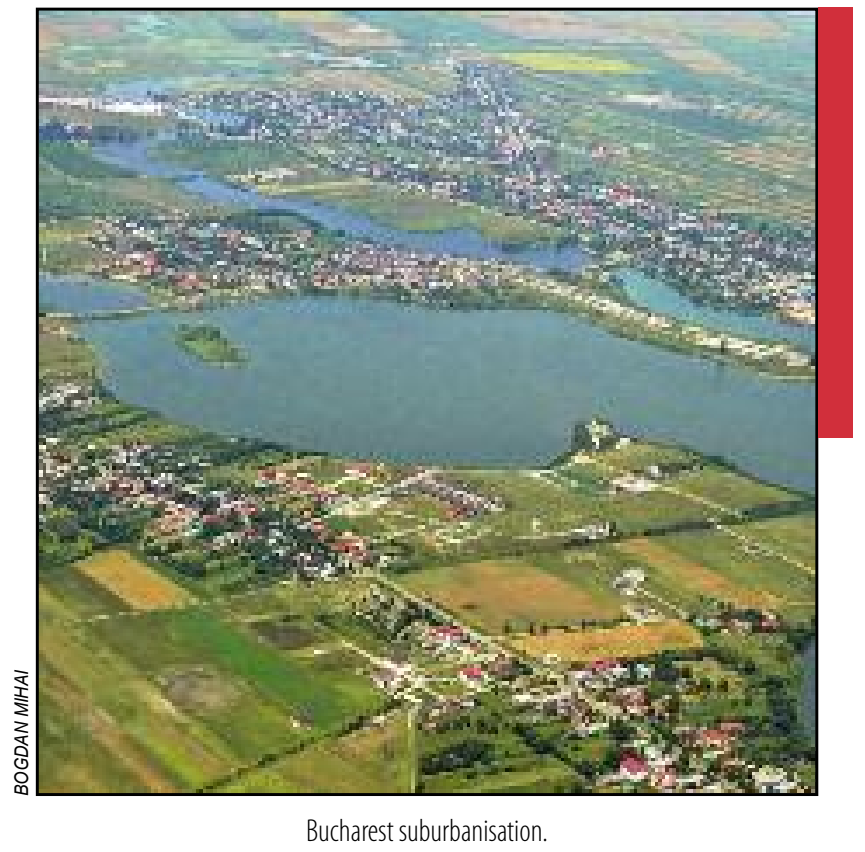




\section{Post-socialist urban growth of Bucharest, Romania - a change detection analysis on Landsat imagery (1984-2010)}

DOI: http://dx.doi.org/10.3986/AGS.709

UDC: $911.375(498.11)$

COBISS: 1.01

ABSTRACT: In this study, Bucharest, the capital city of Romania was selected as a case study. Based on time series of Landsat TM imagery and statistical data, an analysis on urban growth from 1984 to 2010 was performed, using an integrated approach of remote sensing and GIS techniques. The land cover data were validated by CORINE Land Cover maps. The results revealed that rapid urban growth of the Bucharest region led to accelerated land use conversion from cropland to built-up land. The processes of deindustrialization in the core city and industrialization to the ring road represent other driving factors for spatiotemporal pattern of built-up land. The paper will discuss these processes and their impact on economic growth and residential suburbanization of the studied region.

KEY WORDS: Bucharest, Landsat TM, Change detection, Land and real-estate market.

The article was submitted for publication on October $10^{\text {th }}, 2010$.

ADDRESSES:

Bogdan Mihai, Ph.D.

University of Bucharest, Faculty of Geography

Nicolae Balcescu Blvd. 1, 010041 Bucharest, Sect. 1, Romania

E-mail: bogdan@geo.unibuc.ro

Constantin Nistor, Ph.D.

University of Bucharest, Faculty of Geography

Nicolae Balcescu Blvd. 1, 010041 Bucharest, Sect. 1, Romania

E-mail: nistorcosti@yahoo.com

Gabriel Simion, Ph.D.

University of Bucharest, Faculty of Geography

Nicolae Balcescu Blvd. 1, 010041 Bucharest, Sect. 1, Romania

E-mail: gabriel.simion@humangeographies.org.ro 


\section{Introduction}

Post-communist cities of Central and Eastern Europe (CEE) are characterised by an interesting evolution, as the effect of the transition from the centralised urban planning policy to a liberal urban policy based on competitive real-estate market and private investments (Turnock 1997). Although social and economic transitions had different rhythms, for CEE cities urban evolution followed quite the same cyclic phenomena related with the Western European cities (Antrop 2004; Stanilov 2007). Since 1990, every CEE Capital city including Moscow (Russian Federation) - followed almost the same way of reformation through urban policy (Rudolph and Brade 2005). The difference is the effect in landscape change and its temporal resolution. Some capital cities better connected with Western Europe on European transport corridors had the most dynamic urban change - Prague (Sýkora 1999), Budapest (Kiss 2007), Warsaw (Wecławowicz 2005), Ljubljana (Ravbar 1997; Gašperič 2004).

Remote sensing data change detection is one of the most useful methods in analysing the spatiotemporal dynamics of post-socialist cities, because maps and statistical data might be outdates in the context of a short-time period urban change and urban sprawl process (Lu et al. 2004). Recent contributions from international literature integrated Landsat data within the study of urban change and urban sprawl in large urban areas (Qin, Jianwen and Yang Yun 2006; Tang, Wang and Yao 2008; Wu and Zhang 2012). Feranec et al. (2010) mapped in a synoptic formula the changes in the European landscape from 1990 to 2000 and showed for Romania that Bucharest was one of the most dynamic regions.

Our paper is focused on the Bucharest city, ranked the $10^{\text {th }}$ largest capital city in EU by population number. Until 1989, the city gone through the socialist urban policy which increased the building densities mainly residential - within the inner city and the industrial and block of flats areas. Those transformation policies were accelerated after the March 4, 1977 earthquake until the fall of socialist regime in 1989 according to the ideas of the former communist leaders, including demolition of affected areas and systematization of the city centre.

\section{Study area}

The study area is centred on the Bucharest City and its fringe, with a radius of 20-25km (Figure 1). Bucharest City is the country capital and the main urban centre of Romania. The study region covers $2,274 \mathrm{~km}^{2}$, in southern Romania. The relief is mostly flat, with the altitude between 60 to $100 \mathrm{~m}$. This region is characterised by the alternating countryside with a new emerging urban landscape founded in the former villages surrounding Bucharest City.

During the late communist period the state encouraged the expansion of an intensive socialist agriculture around the Bucharest City, within a special district called the Ilfov Agricultural District (Simion, 2010). The National Census from 2002 registered a population of 1.93 million inhabitants in the Bucharest City core, with a slowly decrease at the last census from 2011 when the city counted a population of 1.88 million inhabitants. The density of population is about 8,400 inhabitants per $\mathrm{km}^{2}$. In the end of 2010 local GDP per capita was approximately 13,809 Euro, and was well above the national average (approximately 5.804 Euro) and almost double than the second region with 6,565 Euro. This level of high economic development is best expressed by the investments in the industrial, commercial, services and residential projects.

\section{Methodology}

\subsection{Landsat image processing}

Mapping of spatiotemporal changes was done on four Landsat TM subscenes acquired on 4 August, 1984, 13 August, 1993, 25 August, 2003 and 12 August, 2010 (Table 1). These years are representative for analysing of the urban change of the Bucharest city and for its surrounding region during socialist and post-socialist period.

The change detection analysis combined the multispectral data classification with the GIS mapping. Although spatial resolution is limited to $30 \mathrm{~m}$, the classification results were cross-tabulated with independent 
Bogdan Mihai, Constantin Nistor, Gabriel Simion, Post-socialist urban growth of Bucharest, Romania - a change detection ...

Table 1: Landsat scenes (path183row029) used for change detection analysis.

\begin{tabular}{lcccc}
\hline Sensor & Date & Central point scan time & Resolution & Processing Level \\
\hline Landsat 5 TM & $1984 / 08 / 04$ & 08.32 local time & $30 \mathrm{~m}$ & L1T (orthorectified) \\
Landsat 5 TM & $1993 / 08 / 13$ & 08.25 local time & $30 \mathrm{~m}$ & L1T(orthorectified) \\
Landsat 5 TM & 2003/08/25 & 08.40 local time & $30 \mathrm{~m}$ & L1T(orthorectified) \\
Landsat 5 TM & 2010/08/12 & 08.53 local time & $30 \mathrm{~m}$ & L1T(orthorectified) \\
\hline
\end{tabular}

Data source: Earth Explorer database

land use/land cover (LULC) data - CORINE Land Cover from 1990, 2000 and 2006 - and ground truth validation. The neural network supervised algorithm used hundreds of training areas grouped within four categories, covering almost all the spectral differences within the future classes (built-up land, water, forest and green spaces and cropland). The overall accuracies are between $86-94 \%$ after the comparison of each four images result with the European CORINE Land Cover Data (CLC).

\subsection{Change detection and GIS mapping of change}

Mapping urban growth between 1984 and 2010 was done after the separation of built-up land class. Mapping scale change is completed for two derived case studies of the most dynamic areas represented by northern and the western areas of Bucharest region. Further, analysis was focused on identifying the effect of urban change and growth phenomena in connection with the distance from the city centre by using buffer zones drawn at each $5 \mathrm{~km}$ from centre up to $20 \mathrm{~km}$.

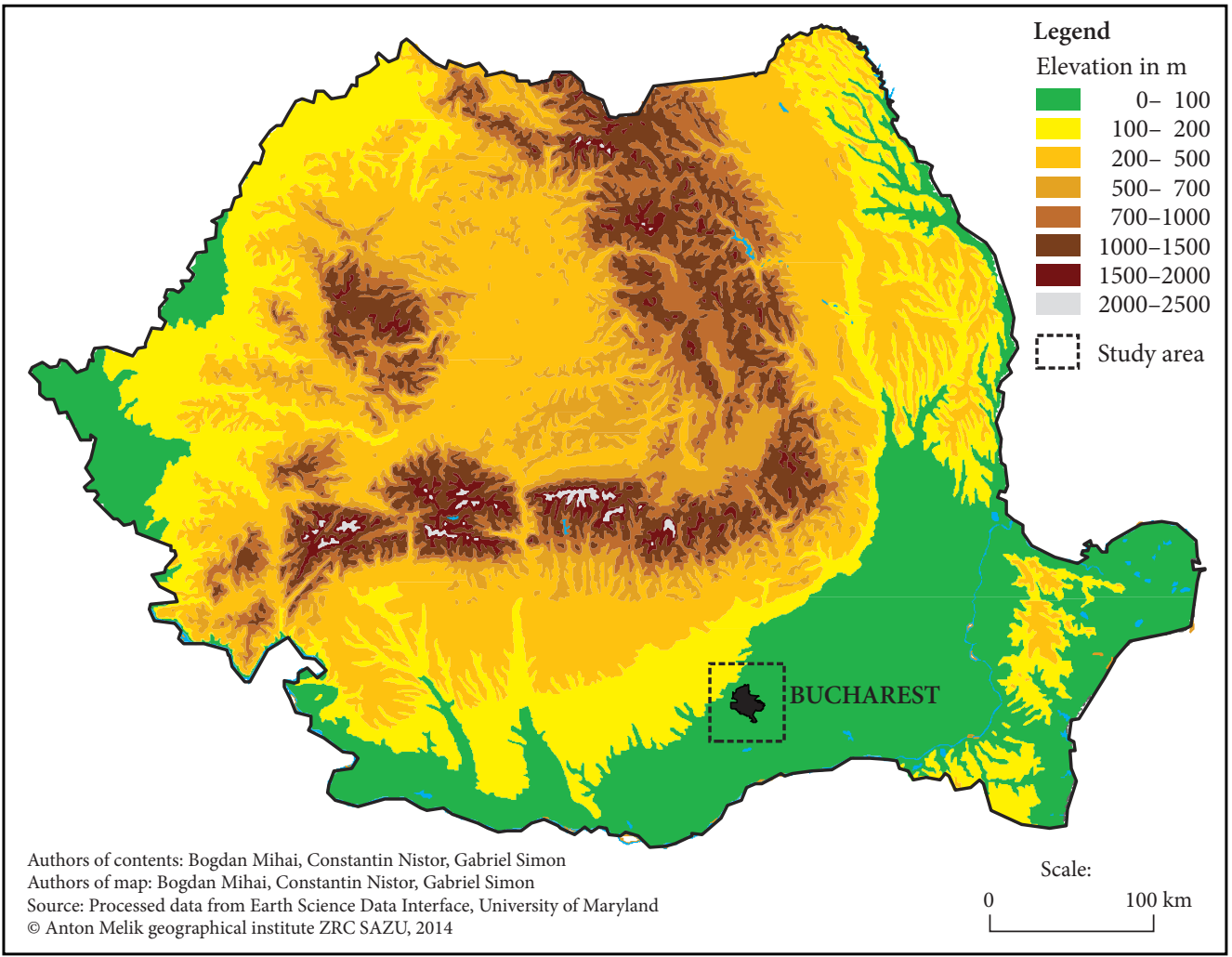

Figure 1: The geographical setting of the study area in Romania. 
Table 2: Synthetic table of confusion matrices.

Ground truth image - CORINE Land Cover

\begin{tabular}{|c|c|c|c|c|c|c|c|c|}
\hline & \multicolumn{4}{|c|}{ User accuracy (\%) } & \multicolumn{4}{|c|}{ Producer accuracy (\%) } \\
\hline & 1984 & $\begin{array}{c}1993 / \\
\text { CLC } 1990\end{array}$ & $\begin{array}{c}2003 / \\
\text { CLC 2000 }\end{array}$ & $\begin{array}{c}2010 / \\
\text { CLC 2006 }\end{array}$ & 1984 & $\begin{array}{c}1993 / \\
\text { CLC } 1990\end{array}$ & $\begin{array}{c}2003 / \\
\text { CLC 2000 }\end{array}$ & $\begin{array}{c}2010 / \\
\text { CLC 2006 }\end{array}$ \\
\hline Built-up land & N/A & 80.91 & 94.93 & 78.16 & N/A & 62.73 & 95.22 & 60.34 \\
\hline Cropland & N/A & 88.42 & 95.89 & 88.26 & N/A & 96.99 & 98.11 & 95.26 \\
\hline Forest land & N/A & 93.37 & 95.01 & 90.92 & N/A & 79.12 & 97.39 & 86.13 \\
\hline Water & N/A & 85.42 & 81.23 & 77.14 & N/A & 34.04 & 71.03 & 50.32 \\
\hline Overall accuracy (\%) & \multicolumn{8}{|c|}{87.84 (1993); 93.86 (2003); 86.92 (2010) } \\
\hline Kappa & \multicolumn{8}{|c|}{$0.70(1993) ; 0.8920(2003) ; 0.70(2010) ;$} \\
\hline
\end{tabular}

Data source: Authors processed the data from classifications on Landsat TM images

Statistical analysis of change detection was derived from the difference between classification layers for three periods: 1984-1993, 1993-2003 and 2003-2010. Confusion matrix was drawn for all of these three periods linking CLC 2006 data with Landsat image 2010 classification (Table 2). Interpretation of the diagrams (Figure 2) allow the identification of changes where regression coefficient $\mathrm{R}^{2}$ is lower than 0.5 .

\section{Results}

\subsection{Spatiotemporal pattern of change detection statistic}

Table 3 and Figure 3 show spatiotemporal patterns of LULC in the Bucharest region from 1984 to 2010. As observed the extent of the LULC classes varied according with the spatial dynamics of the city, which implied an increasing of built-up land and decreasing of cropland.

In the overall period, the built-up land increased with $23.5 \%$, the cropland decreased with $4.2 \%$, forestry and green spaces has remained almost constantly with and increasing of only $1.9 \%$. The projects of water management determined an increase of water bodies, mainly reservoirs and canals for irrigations.

The dynamics of built-up land during socialist time revealed an increase by $15.9 \%$ from 1984 to 1993 , and decrease with $-4.4 \%$ through the transition period from 1993 to 2003. Increasing of built-up land was registered after 2003 when the investments in services, industrial and residential land determined the growth of the built-up land by $11.5 \%$.

a.

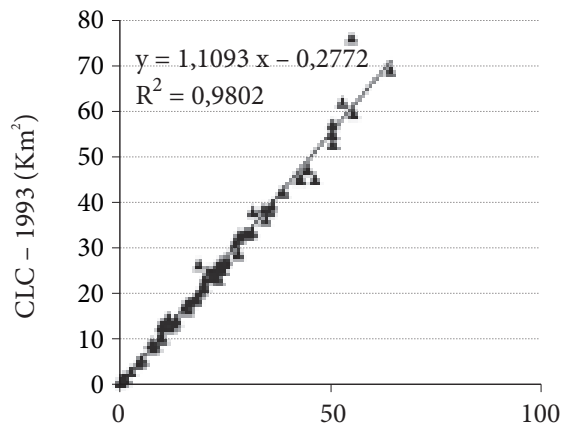

b.

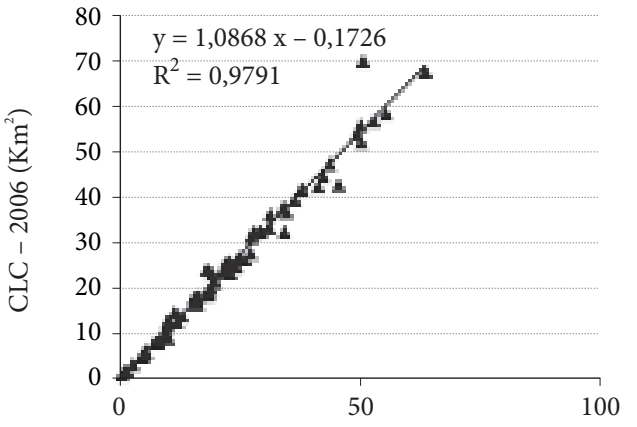

Figure 2: Linear regression graphs. (a) built-up land 1993; (b) cropland 2010. Each point represents an administrative unit from the study area. 
An interesting fact is that classified forest patches for Landsat image 2010 was with a lower accuracy of $60-80 \%$. In this case, the question is if urban growth replaced forest or not? Examination of Figure 3 together with statistical data - change detection matrices for the period 2003 to 2010 - demonstrated an increase of forest patches from 178 to $192 \mathrm{~km}^{2}$.

Analysis of the maps and tables shows the evolution of the built-up land in the Bucharest region from 1984 to 2010 (Figure 3 and Table 3). The expansion of the built-up land was accelerated before 1993, but this trend became negative between 1993 and 2003 and become even faster between 2003 and 2010. Consequently,

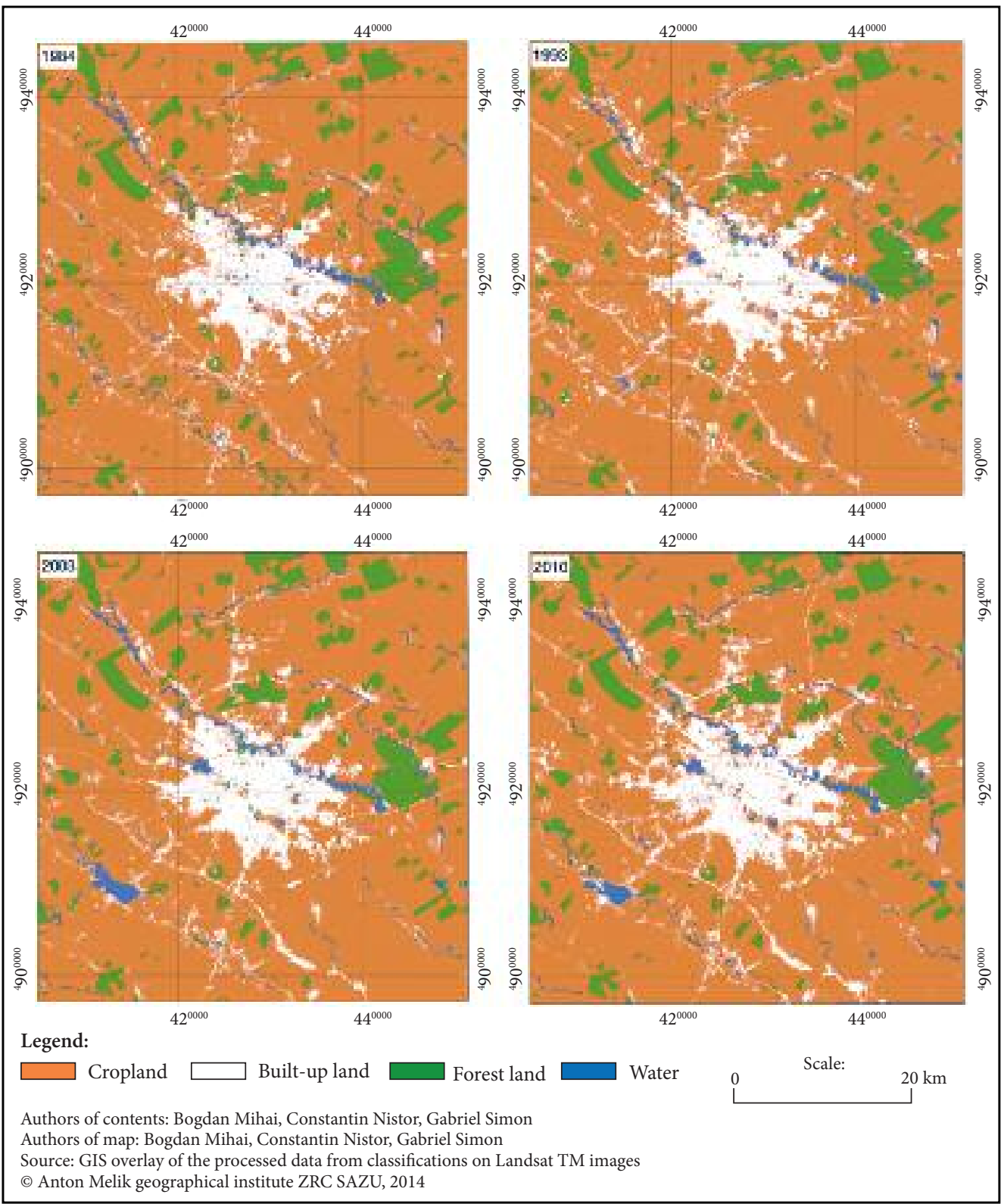

Figure 3: Spatiotemporal evolution of land use/land cover changes from 1984 to 2010. 
along with political and socio-economic influences, spatial pattern of the built-up land of the Bucharest region during the different periods analysed can be described as follows:

1) The 1984-1993 period: During this interval, built-up land of the Bucharest region increased by $15.9 \%$, from $246.86 \mathrm{~km}^{2}$ to $286.04 \mathrm{~km}^{2}$. The classification shows a compact city built-up area (sharp borders) and limited built-up areas for all the settlements around Bucharest. This is related to the so called »systematization of villages " which forbids the developing beyond the strictly defined city borders, and preserving surrounding area for an intensive socialist agriculture. In this period were established several hydro-technical constructions including reservoirs and rivers channels. New runway of Henri Coandă Otopeni airport was built and apartment blocks arose within Bucharest city administrative limit.

2) The 1993-2003 period. Built-up land of the Bucharest region registered a interesting change, with the slightly decrease from $286.04 \mathrm{~km}^{2}$ to $273.4 \mathrm{~km}^{2}$ as an effect of uncertain urban and regional development policy and the economic restructuring. The decrease of built-up area is related with the abandonment/close/demolish of the former socialist plants or demolished of the old/historical buildings.

3) The 2003-2010 period. Built-up land of the Bucharest region increased from $273.4 \mathrm{~km}^{2}$ to $304.92 \mathrm{~km}^{2}$. This period superposes on the most dynamic urban change and urban growth period. Built-up land increases at an approximate rate like that of the peak of socialist time. New urban nuclei erected between main roads, near to the lakes or forests. The new residential ensembles, individual houses, hypermarkets/malls with large parking areas, headquarters of international companies and banks replaced croplands and in few cases forested grounds returned to the former owners by the state. There are also some infrastructure elements that increase the built-up land as the motorway to Ploiești, the new terminal for international flight at Henri Coandă Otopeni airport and the modernization of electrified railway to Ploiești and Braşov - in north - and Constanța - in east -, belonging to the Pan-European Corridor IV.

Table 3: Change rates and directions for the land use/land cover data from 1984 to 2010.

\begin{tabular}{lrrrrrrrrr}
\hline Class Name & $1984 \mathrm{~km}^{2}$ & $1993 \mathrm{~km}^{2}$ & $2003 \mathrm{~km}^{2}$ & $2010 \mathrm{~km}^{2}$ & $\begin{array}{c}1984-1993 \\
(\%)\end{array}$ & $\begin{array}{c}1993-2003 \\
(\%)\end{array}$ & $\begin{array}{c}2003-2010 \\
(\%)\end{array}$ & $\begin{array}{r}1993-2010 \\
(\%)\end{array}$ & $\begin{array}{c}1984-2010 \\
(\%)\end{array}$ \\
\hline Built-up land & 246.86 & 286.04 & 273.4 & 304.92 & 15.9 & -4.4 & 11.5 & 6.6 & 23.5 \\
Cropland & $1,794.72$ & $1,776.25$ & $1,752.06$ & $1,718.58$ & -1.0 & -1.4 & -1.9 & -3.2 & -4.2 \\
Forest land & 200.41 & 184.86 & 205.97 & 204.26 & -7.8 & 11.4 & -0.8 & 10.5 & 1.9 \\
Water & 32.07 & 26.91 & 42.62 & 46.30 & -16.1 & 58.4 & 8.6 & 72.1 & 44.4 \\
\hline
\end{tabular}

Data source: Authors processed data from classifications on Landsat TM images

\subsection{Land cover change with buffer zones}

Another objective of this study was to make a large scale mapping of urban growth in relations with the distance from the city centre. Figure 4 is the result of a buffer zone analysis displaying the effect of LULC on a radius of $20 \mathrm{~km}$. It is focused on only three classes that better define the urban change and city growth: built-up land, water and forest land.

The map shows for the central area of $5 \mathrm{~km}$ city radius more transformation for water and forest-green land than for built-up land. Buffer zone of $5-10 \mathrm{~km}$ is superposed on the city administrative border, where representative change are related to the new developments as residential, commercial, logistic park, on former cropland situated along the main roads. The buffer zone of $10-15 \mathrm{~km}$ shows an important change of built-up land with approximately $50 \%$ of change from 1984 to 2010 due to the abundant new residential land. The buffer zone of 15-20 km shows equilibrium between the percentages of change with only several logistics parks built along the motorway A1 to Pitești.

\section{Discussion}

\subsection{Economic growth and its effect on logistics and services}

Bucharest region is the most dynamic economic area of Romania. Its high developed economy is best expressed by the investments in the industrial, commercial, services and residential projects. 


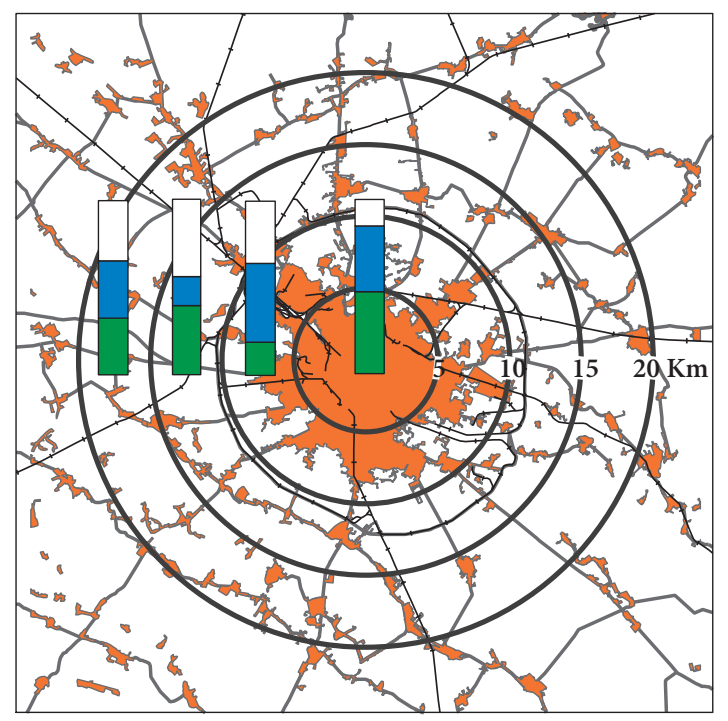

\author{
Legend \\ Change area (\% per class) \\ $\square$ Built-up land \\ Water \\ Forest land
}

Settlement

$\rightarrow$ Railway

- Main road

Scale:

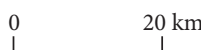

Authors of contents: Bogdan Mihai, Constantin Nistor,

Gabriel Simon

Authors of map: Bogdan Mihai, Constantin Nistor, Gabriel Simon

Source: processed data from classifications on Landsat TM

(C) Anton Melik geographical institute ZRC SAZU, 2014

Figure 4: Buffer zones map of land use/land cover change from 1984-2010.

Industrial and warehouse facilities are built in the western area - along the motorway to Pitesti (A1) where landscape is a mixture of logistic parks with commercial facilities, (Figure 5). These developments are covering 25-30 ha and constructed recently (2005-2013), on the cropland and barren land. Towards the city there are also large commercial investments on the place of former socialist industries. One interesting phenomenon is the industrialization of the ring road introduced by restriction for trucks inside Bucharest City during the last ten years (Simion, 2010).

Service facilities are located in the northern area mainly in the towns of Otopeni and Băneasa (Figure 6). The main attraction of this area was the transport infrastructure: the highway to Ploiești and Brașov, the northern sector of Bucharest City ring railway. The change map show a complex land use pattern with airport, roads and blocks of apartments or individual houses.

In the northern area near the second Bucharest City airport called Băneasa airport (BBU) and up to the ring road and railway is a large area with commercial facilities. The core is the Baneasa Shopping City. In vicinity of the Băneasa forest is a large business park with international corporations' headquarters and showrooms. Another development trend was that barren grounds in Otopeni town - along the main road DN1-E60 - were the subject of office and showroom development in a very short period from 2001 to 2006 .

\title{
5.2 Residential suburbanization
}

Residential suburbanization of Bucharest City is strongly related with the development in industrial, warehouse and services areas. Residential areas appeared as the continuation of those spaces. Northern from OTP airport is a system of residential ensembles, erected after 1997 on barren ground, attracted by the presence of Romania main roads and commercial facilities.

Other residential development areas completed the gap between the city and the ring road and railroad. These areas are still developing and extended the Bucharest city built-up area, although the city expansion was more or less interrupted by the global economic crisis. Except this more compact area of change, Figures 5 and 6 offer a good overview of the spatial impact of urban growth inside Bucharest region. Residential developments extended their limits on $20-30 \mathrm{~km}$ far from the city centre to the northern area, but there are also new residential project in the southern area. 


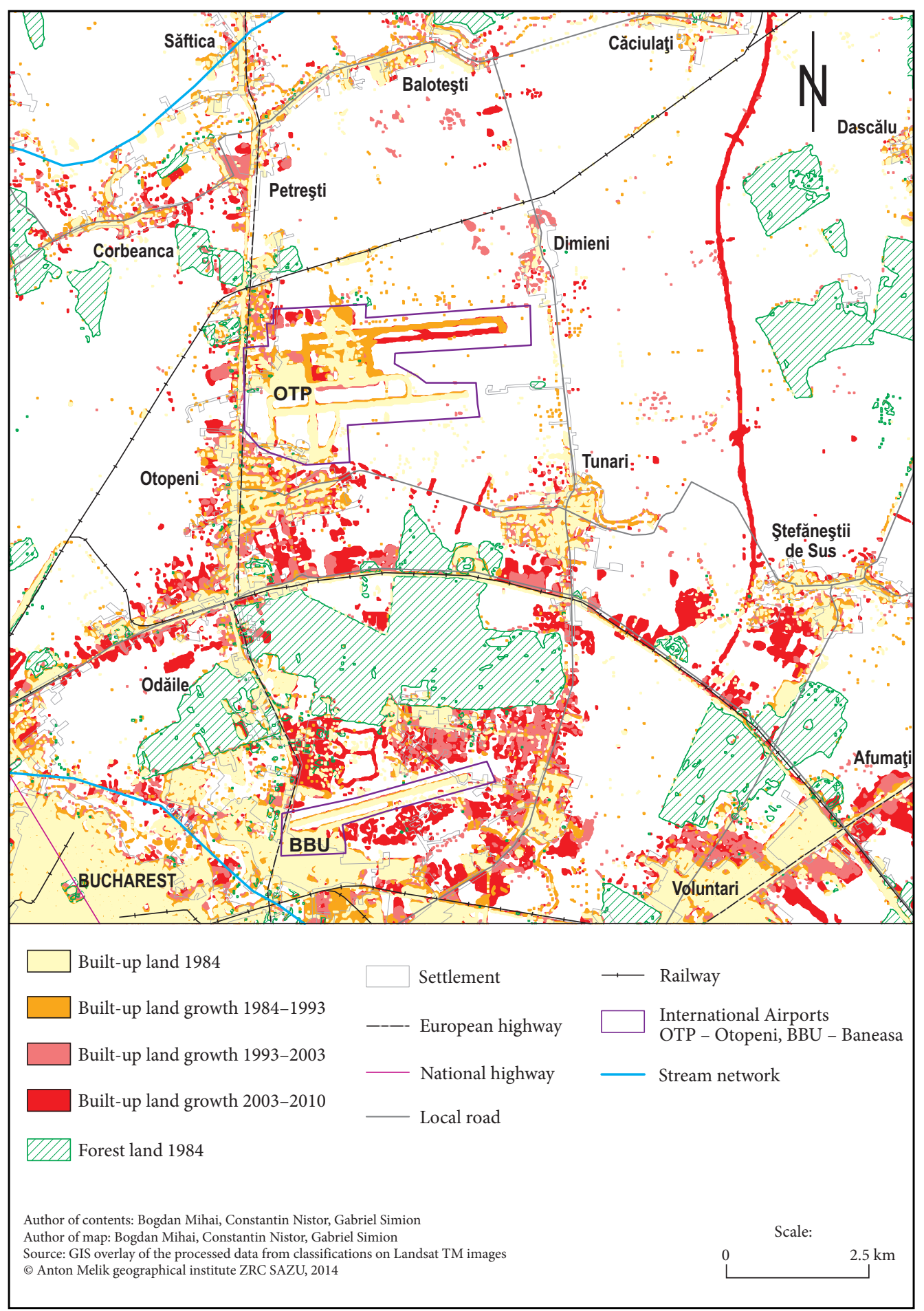

Figure 5: Detailed change maps of western area of the Bucharest region. 


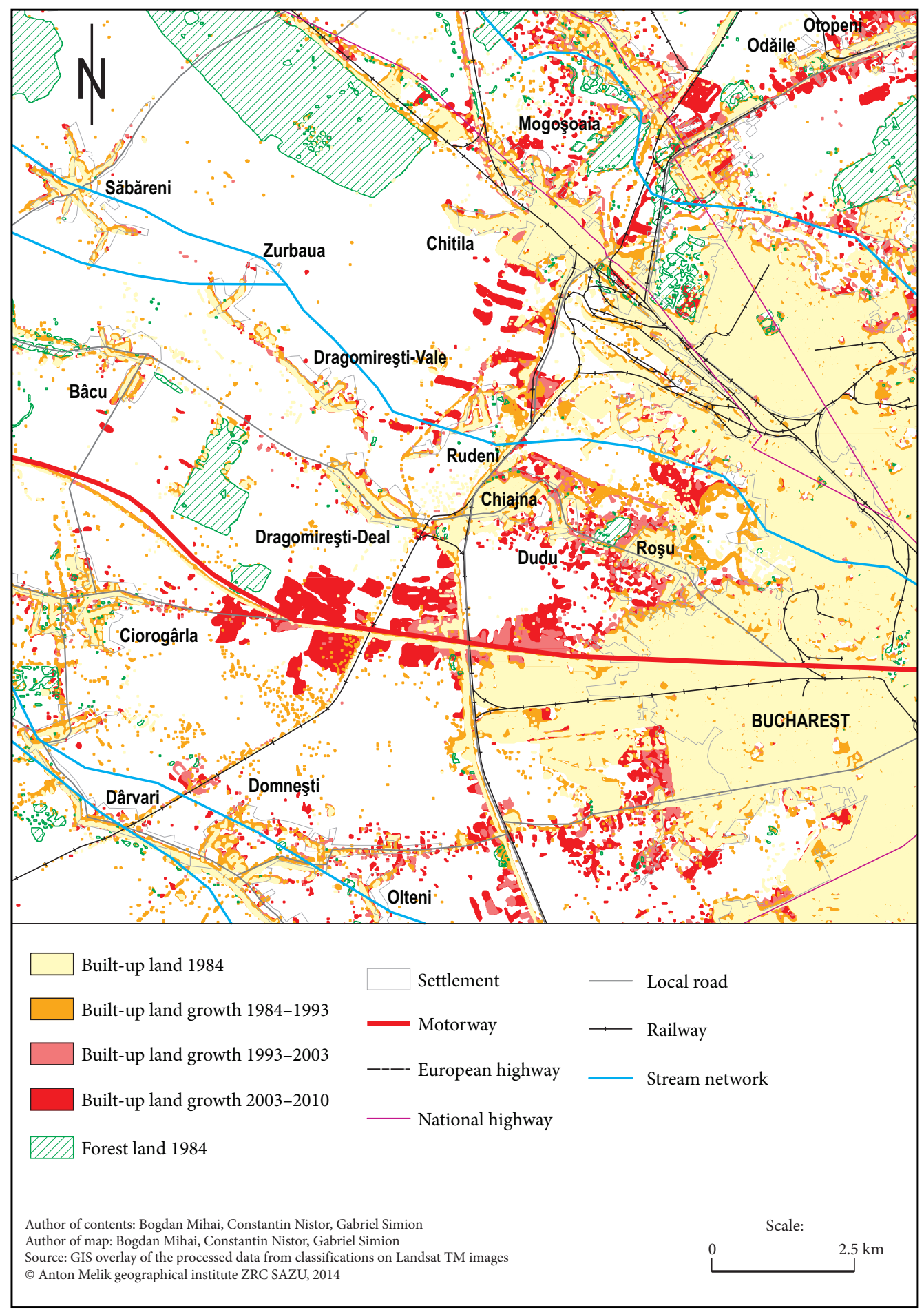

Figure 6: Detailed change maps of northern area of the Bucharest region. 


\section{Conclusion}

Bucharest region featured a delay in urban change and urban growth in comparison with other Eastern European country capitals. One identified tendencies of is the relocation of industrial, commercial, services from the urban core to radial roads and to the outer ring in order to accommodate automobile transportation. The main effect was the deterritorialisation of production and in the future is expected the development of socio-economic centres and expansion nuclei in the suburban area. The new suburban landscape appears as a mixed use of industrial, commercial, office and residential, that can be interpreted as a convergence with the growth of earlier Western European urban regions. The process is well-known Western literature as 'urban sprawl', with associated problems as increasing automobile traffic, air pollution, increasing public cost for providing infrastructure and services.

Mapping of post-socialist period changes at a large scale showed that several areas, especially in the northern and the western regions were attractive for residential, services and warehouse investments due to their position along main roads and available cropland to be converted to such type of uses. The urban growth of Bucharest City became even faster between 2003 and 2010, with a declining trend after 2008 in the context of global economic crisis that affected land market and investments in residential projects. Furthermore, deindustrialization limited the growth of the Bucharest City in the sounding regions because it created available land in the inner city that are converted to other uses - commercial, residential - or are abandoned.

The results can offer a way to evaluate spatiotemporal changes within a post-socialist Capital city. The scale of the analysis is limitative but it is essential to mapping and to validate the qualitative features of the social and economic change.

\section{References}

Antrop, M. 2004: Landscape change and the urbanization process in Europe. Landscape and urban planning 67, 1-4. DOI: http://dx.doi.org/10.1016/S0169-2046(03)00026-4

Feranec, J., Jaffrain, G., Soukup, T., Hazeu, G. 2010: Determining changes and flows in european landscapes 1990-2000 using CORINE land cover data. Applied geography 30-1. DOI: http://dx.doi.org/10.1016/ j.apgeog.2009.07.003

Gašperič P., 2004: The expansion of Ljubljana onto the Ljubljansko Barje moor. Acta Geographica Slovenica 44-2. DOI: http://dx.doi.org/10.3986/AGS44201

Kiss, E. 2007: The Evolution of Industrial areas in Budapest after 1989. The post socialist city - Urban form and space transformations in Central and Eastern Europe after socialism. Dordrecht. DOI: http://dx.doi.org/ 10.1007/978-1-4020-6053-3_19

Lu, D., Mausel, P., Brondízio, E., Moran, E. 2004: Change detection techniques. International journal of remote sensing 25-12. DOI: http://dx.doi.org/10.1080/0143116031000139863

Qin, D., Jianwen, M., Yang Yun, O. 2006: Remote sensing data change detection based on the CI test of Bayesian Networks. Computers and geosciences 32-2. DOI: http://dx.doi.org/10.1016/j.cageo.2005.06.012

Ravbar, M. 1997: Slovene cities and suburbs in transformation. Acta geographica Slovenica 37.

Rudolph, R., Brade, I. 2005: Moscow: processes of restructuring in the post-soviet metropolitan periphery. Cities 22-2. DOI: http://dx.doi.org/10.1016/j.cities.2005.01.005

Simion, G. 2010: Zona Metropolitană București. Geografia agriculturii prin utilizarea tehnicilor GIS. București.

Stanilov, K. 2007: The post socialist city. Urban form and space transformations in Central and Eastern Europe after socialism. DOI: http://dx.doi.org/10.1007/978-1-4020-6053-3_2

Sýkora, L. 1999: Changes in the internal spatial structure of post-communist Prague. GeoJournal 49. DOI: http://dx.doi.org/10.1023/A:1007076000411

Tang, J., Wang, L., Yao, Z. 2008: Analyses of urban landscape dynamics using multi-temporal satellite images: a comparison of two petroleum-oriented cities. Landscape and urban planning 87-4. DOI: http://dx.doi.org/ 10.1016/j.landurbplan.2008.06.011

Turnock, D. 1997: Urban and regional restructuring in Eastern Europe: the role of foreign investment. Geojournal 42-4. DOI: http://dx.doi.org/10.1023/A:1006800930821 
Wecławowicz, G. 2005: The Warsaw metropolitan area on the eve of Poland's integration into the EU. Transformation of cities in Central and Eastern Europe: towards globalization. Tokyo.

Wu, K., Zhang, H. 2012: Land use dynamics, built-up land expansion patterns, and driving forces analysis of the fast-growing Hangzhou metropolitan area, eastern China (1978-2008). Applied geography 34. DOI: http://dx.doi.org/10.1016/j.apgeog.2011.11.006 